\title{
Outras famílias: \\ A construção social da conjugalidade homossexual no Brasil"
}

Luiz Mello**

\begin{abstract}
Resumo
Este artigo propõe uma reflexão sobre a construção social da conjugalidade homossexual no Brasil contemporâneo, especialmente no âmbito do Poder Legislativo, espaço privilegiado de discussão acerca do projeto de lei que institui a parceria civil entre pessoas do mesmo sexo. A análise dos elementos estruturantes nos embates ideológicos decorrentes das disputas em torno do reconhecimento social e jurídico das uniões homossexuais como entidades familiares, também é perpassada por discursos originários da Igreja Católica e de representantes da população homossexual.
\end{abstract}

Palavras-chave: Homossexualidade, Família, Conjugalidade, Parceria Civil.

\footnotetext{
* Este texto contempla, atualizando, parte das conclusões de minha tese de doutoramento, Família no Brasil dos anos 90 - um estudo sobre a construção social da conjugalidade homossexual. Sociologia, UnB, 1999. Recebido para publicação em dezembro de 2003, aprovado em junho de 2004.

** Professor do Departamento de Ciências Sociais, UFG, Goiânia-GO, Brasil. luizman@fchf.ufg.br
}

cadernos pagu (24), janeiro-junho de 2005, pp.197-225. 
Outras famílias

\author{
Different Families: The Social Construction \\ of Homosexual Conjugality in Brazil
}

\begin{abstract}
This article presents some reflections on the social construction of homosexual conjugality in contemporary Brazil, particularly concerning the Legislative sphere - where most of the debate on the law project for civil partnership between people of the same sex has taken place. The main objective is to analyze the structuring elements of the ideological struggles stemming from the disputes around the social and juridical recognition of homosexual unions as familial entities. The discourses that come from the Catholic Church and those of homosexual representatives are also given priority in the analysis.
\end{abstract}

Key Words: Homosexuality, Family, Conjugality, Civil Partnership. 
Luiz Mello

\section{Preliminares}

Ao refletir sobre a construção social da conjugalidade homossexual no Brasil contemporâneo, dois são os objetivos principais: 1) analisar os embates ideológicos decorrentes das tentativas de redefinição das representações e práticas sociais relativas à família, a partir das disputas em torno do reconhecimento social e jurídico das uniões homossexuais, especialmente no âmbito do Poder Legislativo; e 2) explicitar que as relações amorosas estáveis entre homossexuais ${ }^{1}$ podem ser socialmente definidas como uma das modalidades de núcleo familiar conjugal que passa a ter visibilidade social no Brasil dos anos 90, seguindo uma tendência do mundo ocidental.

Entende-se como principal justificativa para a definição do objeto da pesquisa que originou essas reflexões o fato de lésbicas e gays estarem assumindo para si e publicamente, em escala crescente, a linguagem da ternura e da preocupação sentimental em suas parcerias amorosas ${ }^{2}$, bem como dando mostras de uma

\footnotetext{
${ }^{1}$ Utilizo as categorias "homossexualidade", "homossexual" (como adjetivo) e "homossexual" (como substantivo) para referir-me, nos dois primeiros casos, ao conjunto de práticas e representações sociais relacionadas aos vínculos emocionais e sexuais entre iguais biológicos e, no terceiro caso, ao ser humano que estabelece, no imaginário ou no mundo real, tais vínculos. É notório que o campo semântico da homossexualidade - e mais ainda do homossexualismo - $e$ da "identidade homossexual" está constitutivamente marcado pelo contexto médico-patologizante que lhe deu origem na Europa da segunda metade do século XIX. Em conseqüência, a opção pelo uso dessas categorias, inclusive no título deste artigo, explicita as dificuldades teóricas ainda subjacentes à compreensão da sexualidade e da conjugalidade a partir de fundamentos sociais e históricos. Para um debate sobre os impasses teóricos do uso das expressões homossexualidade, homoerotismo, homofilia e congêneres, ver MELlO, Luiz. Família no Brasil dos anos 90 - um estudo sobre a construção social da conjugalidade homossexual. Tese de Doutorado, Sociologia, UnB, 1999.

2 Costa, Jurandir Freire. A inocência e o vício: estudos sobre o homoerotismo. Rio de Janeiro, Relume Dumará, 1992.
} 
Outras famílias

reedição daquilo que Ariès ${ }^{3}$ chama de "sentimento da família", redefinindo padrões de conjugalidade $e$ parentalidade $e$ rompendo com os limites convencionais definidores da instituição familiar, até recentemente restrita ao âmbito do heterocentrismo $e$ da heterossexualidade compulsória, por meio dos quais se pretende negar, respectivamente, a existência e a validade da existência de expressões afetivas e sexuais não integrantes do universo das relações heterossexuais. ${ }^{4}$

A conseqüência mais direta dessas transformações é a desconstrução, mesmo que parcial, da imagem "perversa" $e$ "pouco humana" associada a lésbicas e gays, embora continuem a ser preponderantes as representações sociais que os definem como "máquinas sexuais", cujas identidades seriam construídas, afirmadas e vivenciadas em torno do exercício permanente da sexualidade, especialmente no caso dos homens. ${ }^{5}$ Por meio da constituição de casais conjugais, cujos membros geralmente se autodefinem como uma família, os homossexuais passam a desvincular-se dessas representações sociais e reivindicam não mais apenas o direito à cidadania, em nível individual, mas, também, o direito à constituição de grupos familiares, integrandose ao rol de sujeitos sociais portadores de demandas que, no mundo ocidental, convencionalmente realizam-se por meio da constituição do casal conjugal e da socialização de crianças - filhos biológicos ou adotivos.

\footnotetext{
3 ARIÈs, Philippe. História Social da Criança e da Família. Rio de Janeiro, Guanabara, 1981.

4 ButLer, Judith. Problemas de gênero: feminismo e subversão da identidade. Rio de Janeiro, Civilização Brasileira, 2003.

5 Sobre a "cultura sexual" de homens homossexuais, destacam-se as análises propostas por POLLAK, Michael. Os homossexuais e a Aids: sociologia de uma epidemia. São Paulo, Estação Liberdade, 1990; ROTELlo, Gabriel. Comportamento sexual e AIDS: a cultura gay em transformação. São Paulo, Summus, 1998; Trevisan, João Silvério. Devassos no Paraíso. São Paulo, Max Limonad, 1986
} 
As representações sociais relativas à família, por sua vez, estão sofrendo alterações significativas no Brasil e no mundo, sendo a luta de lésbicas e gays pela conquista de legitimidade social para suas relações amorosas estáveis uma das que aponta para questionamentos profundos acerca dos fundamentos estruturadores do ideário de família conjugal. ${ }^{6}$ Da mesma forma, as lutas em torno do reconhecimento social e jurídico da dimensão familiar das uniões homossexuais estão constitutivamente associadas à afirmação/negação do mito da complementaridade dos sexos e dos gêneros, o qual restringe ao casal homem-mulher a competência moral e social para desempenhar as funções atribuídas à instituição familiar, especialmente no que diz respeito à parentalidade. ${ }^{7}$ Não se pode esquecer, por outro lado, que o não reconhecimento social e jurídico das relações amorosas estáveis entre gays e entre lésbicas como uma família é a principal interdição que atinge os homossexuais no contexto da realidade brasileira, especialmente no tocante à socialização de crianças, estando fundada numa defesa irrestrita da conjugalidade e da parentalidade como possibilidades limitadas ao universo da norma heterocêntrica. ${ }^{8}$

\footnotetext{
${ }^{6}$ Instigantes reflexões acerca das transformações no âmbito da família na atualidade podem ser encontradas em Interseçóes - Revista de Estudos Interdisciplinares (Dossie Comportamentos Familiares). UERJ, RJ, ano $3, \mathrm{n}^{\circ} 2$, jul./dez. 2001; VAITSMAN, Jeni. Flexíveis e plurais: identidade, casamento e família em circunstâncias pós-modernas. Rio de Janeiro, Rocco, 1994.

7 Para uma discussão sobre parentalidade e homossexualidade, ver BENKOV, Laura. Reinventing the Family: the Emerging Story of Lesbian and Gay Parents. New York, Crown Publishers, 1994; POLLACK, Jill S. Lesbian and Gay Families: Redefining Parenting in America. New York, Franklin Watts, 1995; e SAFFRON, Lisa. What about the Children? Sons and Daughters of Lesbian and Gay Parents Talk about Their Lives. New York, Cassel, 1996.

8 Em relação ao debate acerca da conjugalidade homossexual na sociedade estadunidense, ver BAIRD, Robert \& ROSENBAUM, Stuart. (eds.) Same-sex Marriage: the Moral and Legal Debate. New York, Prometheus Books, 1997; CABAJ, Robert P. \& PurCell, David W. (eds.) On the Road to Same-sex Marriage: A Supportive Guide to Psychological, Political, and Legal Issues. San Francisco, Josey-Bass Publishers, 1997.
} 
Outras famílias

Seguramente, não é exagerado dizer que setores da sociedade brasileira, geralmente influenciados por ideologias familiaristas e naturalistas de origem religiosa, têm se revelado bastante resistentes aos discursos e às vivências de lésbicas e gays que procuram afirmar o direito à liberdade de orientação sexual e a legitimidade dos agrupamentos familiares que fogem ao padrão nuclear moderno, formado por um "homem instrumental" unido a uma "mulher expressiva", juntos socializando crianças felizes, nos termos do modelo parsoniano. ${ }^{9}$ Isso porque a homossexualidade, por si só, é vista por muitos como um misto de pecado-doençacrime, despertando rejeições de intensidades variadas em diferenciados segmentos sociais, o que faz dos homossexuais um dos agrupamentos mais atingidos pelas complexas lógicas de intolerância, preconceito e discriminação. Exemplo disso é que ainda hoje emergem, em várias partes do país, iniciativas que colocam em xeque a legitimidade das relações afetivo-sexuais entre pessoas do mesmo sexo. Dois casos são emblemáticos: 1) a apresentação, na Assembléia Estadual do Rio de Janeiro, de projeto de lei que prevê apoio do governo estadual a organizações não-governamentais e associações religiosas dedicadas a "ajudar" homossexuais que queiram "tornar-se" heterossexuais; 2) a organização, por psicólogos evangélicos, de abaixo-assinado destinado a revogar a Resolução $n^{\circ} 01 / 99$, do Conselho Federal de Psicologia, que estabelece normas de atuação em relação à questão da orientação sexual. Em ambos os casos, está-se diante de formas nada sutis de repatologização da homossexualidade, a partir de uma perspectiva que insiste em definir lésbicas e gays como doentes que precisam ser tratados.

Em contrapartida, aliando-se ao conjunto de todos os oprimidos e discriminados, ainda que muitas vezes também se transformem em opressores e discriminadores, lésbicas e gays emergem na cena política ao longo do século XX - no Brasil,

9 PARSONS, Talcott \& BALES, Robert F. Family, Socialization and Interaction Process. Nova York, The Free Press, 1955. 
particularmente nos últimos 25 anos - e questionam a universalidade dos valores heterossexistas vigentes. São homens e mulheres que, transcendendo os limites de classe, sexo, gênero, raça, etnia, religião, geração, nacionalidade e orientação ideológica, enfim, transcendendo praticamente todas as fronteiras, trazem em seus pensamentos, intenções $e$ atos, ainda que de forma nem sempre intencional e deliberada, a marca (estigma) im(ex)plícita da transgressão, desafiando fundamentos básicos da normatividade social por meio de suas vivências amorosas $e$ sexuais. ${ }^{10}$

Nesse contexto, países do norte da Europa - Dinamarca, Suécia e Noruega - começam a reconhecer, a partir do final da década de 80 , estatuto legal às relações amorosas estáveis entre gays e entre lésbicas, inclusive sob o argumento de que a iniciativa fortaleceria o estabelecimento de relações monogâmicas $e$ duradouras, contribuindo para diminuição das possibilidades de infecção pelo HIV, além de assegurar amparo legal aos parceiros de homens mortos em decorrência da epidemia. Desde então, nos países onde a homossexualidade não é tipificada como crime, a luta pelo reconhecimento da legitimidade e da legalidade das relações amorosas estáveis homossexuais tem sido uma das principais demandas do movimento de afirmação dos direitos de lésbicas e gays, o qual geralmente encontra no movimento feminista um aliado imprescindível. No momento atual, Bélgica, Espanha e Holanda são os únicos países que aprovaram leis dispondo sobre o casamento entre pessoas do mesmo sexo, enquanto apenas nos dois últimos está assegurada a possibilidade de adoção de crianças por casais de gays e de lésbicas. França, Alemanha, Finlândia, Suécia, Noruega, Dinamarca, Islândia e vários outros países da Europa permitem a união civil entre lésbicas e entre gays - o que não deve ser confundido com

\footnotetext{
${ }^{10}$ Estigma aqui deve ser pensado a partir da clássica abordagem de GOFFMAN, Erving. Estigma: notas sobre a manipulação da identidade deteriorada. Rio de Janeiro, Zahar, 1982.
} 
Outras famílias

"casamento homossexual" -, conferindo diversos benefícios e responsabilidades aos membros da díade. Buenos Aires, desde julho de 2003, tornou-se a primeira cidade da América Latina a reconhecer estatuto legal a uniões homossexuais, ainda que seu alcance restrinja-se à extensão do seguro saúde, ao direito de curatela e a crédito conjunto para financiamentos. Nos Estados Unidos, após os episódios envolvendo a emissão de certidões de casamento pelo Prefeito de São Francisco (suspensa por decisão da Suprema Corte da Califórnia), o estado de Massachusetts passou a ser o primeiro a reconhecer legalmente o casamento entre pessoas do mesmo sexo, desde maio de 2004. Essas duas iniciativas foram responsáveis pelo acirramento dos debates acerca do "casamento gay" nos Estados Unidos, inclusive na forma de uma proposta de emenda à constituição que restringiria a possibilidade de casamento ao casal heterossexual, defendida pelo presidente George W. Bush.

No Brasil em particular, deve-se registrar que o ano de 1995 é um marco para a luta homossexual, tendo em vista três fatos principais: a realização, no mês de junho, no Rio de Janeiro, da 1a Conferência da Associação Brasileira de Gays, Lésbicas e Travestis (ABGLT) e da 17a Conferência da International Lesbian and Gay Association (ILGA) e a apresentação, pela Deputada Marta Suplicy, do Projeto de Lei $n^{\circ} 1151 / 95$, que institui a união civil entre pessoas do mesmo sexo, atendendo demanda de grupos homossexuais organizados do País. ${ }^{11}$ Especialmente a partir da publicização deste projeto de lei, os meios de comunicação de massa, liderados pela televisão, passaram a dar cobertura ostensiva - e muitas vezes sensacionalista - à discussão sobre a união civil entre pessoas do mesmo sexo, denominando-a, a contragosto da autora da proposição, de "casamento gay". No embalo de todos esses debates, começam a eclodir pelo país

${ }^{11}$ O Projeto de Lei $n^{\circ}$ 1151/95 é explicitamente inspirado na legislação sueca, razão pela qual, inclusive, a Sra. Barbro Westerholm, deputada do Parlamento Sueco, foi convidada a participar dos debates na Câmara dos Deputados, em uma das reuniões da Comissão Especial destinada a apreciar a proposição. 
inúmeras demonstrações de apoio e repulsa à idéia de uma conjugalidade homossexual, as quais encontram nos grupos de lésbicas $e$ gays $e$ nas igrejas católica $e$ evangélicas seus antagonistas principais. Se as pressões sobre os parlamentares parecem constituir o objetivo original dessas manifestações, muitas vezes a conquista de aliados fora do âmbito do Poder Legislativo também emerge, por si só, como objetivo a ser alcançado.

Com os debates acerca do Projeto de Lei $n^{\circ} 1.151 / 95$, a luta dos homossexuais pelo reconhecimento de sua cidadania $e$ direitos humanos alcançou um novo patamar na cena política brasileira. Até então as discussões acerca do eventual direito de lésbicas e gays a não discriminação por orientação sexual restringiam-se às esferas do trabalho, da moradia, do lazer e do acesso a bens e serviços. Com a apresentação do referido Projeto setores expressivos da sociedade brasileira associam-se a um inédito diálogo, nem sempre fácil, acerca da prerrogativa de lésbicas e gays usufruírem de direitos humanos e de cidadania próprios ao âmbito da conjugalidade e da parentalidade. À medida que tais debates se ampliavam em extensão $e$ profundidade, ficava cada vez mais claro que, pela primeira vez na história brasileira, o Congresso Nacional e a sociedade em geral estavam perante uma reivindicação de direitos que implicava o questionamento da norma heterocêntrica que desde sempre estruturara os pressupostos éticos, morais e legais relativos à família patriarcal. É nesse contexto geral que as discussões acerca do Projeto podem ser compreendidas como um indicativo de que lésbicas e gays, na qualidade de cidadãos, percebem-se discriminados e excluídos do usufruto de direitos humanos fundamentais na esfera da família, o que implicaria a negação de sua dignidade e intrínseca humanidade, já que seus vínculos afetivo-sexuais estáveis não contam com a proteção legal do Estado, embora não sejam juridicamente definidos como ilegais, nem cientificamente reconhecidos como patológicos.

Vale dizer, ainda, que a divulgação, na mídia, desde a segunda metade dos anos 90, de decisões do Poder Judiciário 
Outras famílias

relativas aos direitos conjugais e parentais no âmbito de casais homossexuais também tem colocado a sociedade brasileira diante da facticidade da homossexualidade e das uniões homossexuais. Em 31 de outubro de 2002, por exemplo, foi concedida, pelo juiz da $2^{\text {a }}$ Vara de Órfãos do Rio de Janeiro, a tutela definitiva de Francisco, filho biológico da cantora Cássia Eller, falecida em fins de 2001, a sua companheira, Eugênia. Embora a decisão da Justiça não tenha criado jurisprudência, pois se tratou de acordo entre as partes (Eugênia e o pai da cantora), foi aberto precedente importante, demonstrando a tendência do direito de considerar e respeitar novas formas de organização familiar. Os amplos debates que ocorreram ao longo dos dez meses desta disputa judicial contribuíram significativamente para o aprofundamento da discussão sobre os direitos de casais homossexuais, na sociedade brasileira. Embora tais decisões ainda sejam em número reduzido e muitas vezes tratem as uniões afetivo-sexuais entre lésbicas $e$ gays sob a ótica do direito comercial, o que se observa é que começa a ganhar aceitação, especialmente no judiciário do Rio Grande do Sul, a idéia de que os casais homossexuais também constituem unidades familiares. ${ }^{12}$

Seguramente, esse processo de lutas em torno da redefinição de representações e práticas sociais relativas à família não se restringe ao universo da homossexualidade. Ao contrário, lésbicas e gays, particularmente no Brasil, só muito recentemente vêm assumindo publicamente um desejo de integração social plena por meio do reconhecimento da dimensão familiar de suas relações amorosas estáveis, estando a maior parte das lutas por hegemonia em torno da questão da família situadas no âmbito da heterossexualidade. Assim, também as pessoas de sexos diferentes, que se elegem como parceiros afetivo-sexuais e que constroem arranjos familiares que não se enquadram nos estreitos contornos da família conjugal moderna, igualmente encontram-se

${ }^{12}$ DiAS, Maria Berenice. Homoafetividade: o que diz a justiça! Porto Alegre, Livraria do Advogado, 2003. 
buscando a superação da rejeição social e vêm afirmando seu desejo de serem reconhecidas como cidadãos/cidadãs cujas famílias devem ser respeitadas e protegidas não só pelo Estado, como também por toda a sociedade. Como exemplos deste permanente processo de transformação das representações $e$ práticas sociais relativas à família no Brasil, podem ser destacadas as longas lutas pelo direito ao divórcio e ao reconhecimento social e jurídico das uniões concubinárias enquanto entidades familiares, assim como os conflitos relacionados à superação das discriminações e preconceitos que ainda atingem as famílias monoparentais, os casais sem filhos e os inter-raciais. ${ }^{13}$

\section{Estado, sociedade civil e os debates sobre homoconjungalidades}

Em nossa análise, alguns sujeitos enunciantes foram privilegiados ao longo das investigações empíricas dos discursos acerca das relações amorosas estáveis entre homossexuais. A escolha destes sujeitos norteou-se, em princípio, por seu envolvimento explícito nos embates ideológicos em torno da questão da família, da sexualidade e da (i)legitimidade social das relações amorosas estáveis entre pessoas do mesmo sexo, tanto na esfera do Estado quanto na da sociedade civil. Neste sentido, analisar os debates acerca do projeto de lei que institui a união civil entre pessoas do mesmo sexo, na Câmara dos Deputados ${ }^{14}$,

\footnotetext{
${ }^{13}$ A diversidade de estruturas familiares e de relacionamentos característica do mundo ocidental contemporâneo pode ser observada em HITE, Shere. Relatório Hite sobre a familia: crescendo sob o domínio do patriarcado. Rio de Janeiro, Bertrand Brasil, 1995. Especificamente no caso do Brasil, ver CARVALHO, Maria do Carmo Brant. (org.) A familia contemporânea em debate. São Paulo, EDUC, 1995; e CORRÊA, Mariza et alii. Colcha de retalhos: estudos sobre a familia no Brasil. São Paulo, Brasiliense, 1982.

${ }^{14}$ Ainda em dezembro de 1996, na mesma semana em que o Projeto foi aprovado na Comissão Especial, na forma do Substitutivo proposto pelo Relator, Deputado Roberto Jefferson, teve lugar a primeira das inúmeras vezes em que se tentou, infrutiferamente, discutí-lo e votá-lo na esfera do Plenário da Câmara dos Deputados. Tais tentativas não chegaram a se consumar, ora por pressão dos
} 
Outras famílias

pareceu-nos uma estratégia adequada para compreender como estaria constituindo-se a construção social da conjugalidade homossexual, especialmente por ser o Legislativo o Poder que melhor expressa os acordos estabelecidos entre os membros de uma sociedade democrática, que são representados por parlamentares livremente eleitos. ${ }^{15}$ Assim, no âmbito das discussões na Câmara dos Deputados, foram analisados os discursos de: a) 20 parlamentares que se pronunciaram na Comissão Especial destinada a discutir e aprovar parecer preliminar ao referido Projeto $^{16}$ - que funcionou no período de junho a dezembro de 1996; b) 9 representantes da sociedade civil e uma parlamentar estrangeira, que realizaram exposições ao

parlamentares contrários à matéria, que temiam sua aprovação, ora por solicitação da autora, Deputada Marta Suplicy, que recuou, em momentos que pareciam indicar que o Projeto seria rejeitado no Plenário. Deve ser também destacado que no início da legislatura passada (1999-2003), o mesmo Deputado Roberto Jefferson apresentou o Projeto de Lei n 5252/01, que "cria e disciplina o PACTO DE SOLIDARIEDADE entre as pessoas e dá outras providências". Em linhas gerais, tal Projeto em muito assemelha-se ao Substitutivo aprovado na Comissão Especial, com a diferença substantiva de ser o pacto de solidariedade um instrumento que não está restrito à esfera do casal formado por pessoas do mesmo sexo.

${ }^{15}$ Rodrigues, Almira. Cidadania nas Relações Afetivo-Sexuais no Brasil Contemporâneo: Uma Questão de Políticas Públicas. Tese de Doutorado. Sociologia, UnB, 1998.

${ }^{16}$ Parlamentares que se pronunciaram pela aprovação do Projeto: Deputada Marta Suplicy (PT/SP) - Autora do Projeto; Deputado Roberto Jefferson (PTB/RJ) - Relator e Autor do Substitutivo; Deputada Maria Elvira (PMDB/MG) Presidente da Comissão Especial; Deputado Fernando Lyra (PSB/PE); Deputado José Genoíno (PT/SP); Deputado Lindberg Farias (PCdoB/RJ); Deputada Alzira Ewerton (PPB/AM); Deputado Fernando Gabeira (PV/RJ); Deputado Tuga Angerami (PSDB/SP); Deputada Laura Carneiro (PFL/RJ); Deputado Nilmário Miranda (PT/MG); Deputado Sérgio Carneiro (PDT/BA); Deputada Marilu Guimarães (PFL/MS); Deputado Fernando Gonçalves (PTB/RJ); Deputado Jair Meneguelli (PT/SP). Parlamentares que se pronunciaram pela rejeição do Projeto: Deputado Salvador Zimbaldi. (PSDB/SP); Deputado Philemon Rodrigues (PTB/MG); Deputado Wagner Salustiano (PPB/SP); Deputado Severino Cavalcanti (PPB/PE); Deputado Jorge Wilson (PPB/RJ). 
longo das 9 audiências públicas da referida Comissão ${ }^{17}$ - período de junho a dezembro de 1996; e c) 27 parlamentares que se manifestaram acerca do mérito do Projeto na instância do Plenário - período de outubro de 1995 a dezembro de $1997 .{ }^{18}$

Já em relação ao posicionamento de lésbicas e gays e da Igreja Católica, na qualidade de representantes da sociedade civil que têm participação fundamental nos debates, foram utilizados como fontes de pesquisa os seguintes documentos: 1) relatórios do VIII Encontro Brasileiro de Lésbicas e Gays (Curitiba, 1995), do IX Encontro Brasileiro de Gays, Lésbicas e Travestis (São Paulo, 1997) e do X Encontro Brasileiro de Gays, Lésbicas e Travestis

${ }^{17}$ Os representantes da sociedade civil que participaram, como expositores convidados, das audiências públicas promovidas pela Comissão Especial foram: Luiz Mott, Professor Titular da Universidade Federal da Bahia (UFBA), Presidente do Grupo Gay da Bahia (GGB) e Secretário de Direitos Humanos da Associação Brasileira de Gays, Lésbicas e Travestis (ABGLT); Toni Reis, Professor, Presidente do Grupo Dignidade - Conscientização e Emancipação Homossexual, do Paraná, e Secretário-Geral da ABGLT; Cláudio Pérsio Carvalho Leite, Psiquiatra e Psicanalista; Eduardo Mascarenhas, Psiquiatra e Psicanalista; Ronaldo Pamplona, Psiquiatra e Psicodramatista; Luiz Edson Fachin, Professor de Direito da Família, na Universidade Federal do Paraná e na PUC do Paraná; Ricardo Brisolla Balestreri, Presidente da Seção Brasileira da Anistia Internacional, Diretor-Geral do Programa Nacional de Educação para Cidadania e Presidente do Comitê Coordenador do Centro Regional de Recursos Educativos do Instituto Interamericano de Direito Humanos, na Costa Rica; Leonard M. Martin, Padre e Diretor do Instituto Teológico - Pastoral do Ceará - e Presidente em exercício da Sociedade Brasileira de Teologia Moral; Simone Nogueira, Coordenadora-Geral da Comissão de Direitos Humanos da Ordem dos Advogados do Brasil do Distrito Federal; Barbro Westerholm, Deputada do Parlamento Sueco, médica e professora universitária.

${ }^{18}$ As cópias dos pronunciamentos no Plenário foram solicitadas à Seção de Documentação Parlamentar, do Centro de Documentação e Informação da Câmara dos Deputados, em março de 1999. Naquela ocasião, só se encontravam à disposição do público os pronunciamentos realizados até dezembro de 1997. A despeito dos seis anos transcorridos desde então, acreditase que os pronunciamentos a que se teve acesso são bastante ilustrativos dos argumentos que até hoje são utilizados pelos parlamentares, no Plenário, em defesa da aprovação ou rejeição do Projeto, especialmente no que diz respeito à eventual dimensão familiar das uniões homossexuais. 
Outras famílias

(Maceió, 2001); 2) relatórios do $1^{\circ}$ e do $2^{\circ}$ Encontros da Familia GLT (gay, lésbica e travesti), organizados pela ABGLT, em Curitiba, em 1998 e 1999; 3) todos os números da revista SuiGeneris ( $\mathrm{n}^{\circ}$ s 1 a 55, de janeiro de 1995 a março de 2000); 4) Pronunciamento sobre a família (1996) e A Propósito do Projeto de Lei de União Civil de Pessoas do Mesmo Sexo (1996), ambos de autoria da Confederação Nacional dos Bispos do Brasil (CNBB); 5) Consideraçóes sobre os projetos de reconhecimento legal das unióes entre pessoas homossexuais (2003), Algumas Reflexóes acerca da Resposta a Propostas Legislativas sobre a Não-discriminação das Pessoas Homossexuais (1992) e Carta aos Bispos da Igreja Católica sobre o Atendimento Pastoral das Pessoas Homossexuais (1986), todos de autoria da Congregação para a Doutrina da Fé, do Vaticano.

Pode-se dizer que os parlamentares que se pronunciaram em relação ao mérito do Projeto na Câmara dos Deputados dividem-se em dois grupos principais: os que reconhecem a legitimidade das uniões homossexuais (predominantes entre os que se manifestaram na Comissão Especial) e os que negam tal legitimidade (prevalecentes entre os que expressaram posicionamentos no Plenário). Tanto na Comissão quanto no Plenário, seis pressupostos são afirmados e negados, respectivamente, pelos parlamentares favoráveis e contrários: a) o Projeto não confere estatuto familiar às uniões homossexuais e é, portanto, constitucional; b) a liberdade de orientação sexual é um direito humano e de cidadania; c) a família é uma instituição social e histórica, sujeita a transformações; d) a conjugalidade não se confunde com a parentalidade; e) a proteção do Estado às uniões homossexuais deve ser pensada numa perspectiva laica $e$, portanto, não religiosa; f) uniões homossexuais e uniões heterossexuais, além de serem ambas fundadas no amor, devem receber tratamento igualitário na esfera pública.

A questão da constitucionalidade do Projeto foi central nesses debates. Em face do amparo legal às uniões homossexuais ter sido proposto pela via de um projeto de lei e não de uma 
emenda constitucional ${ }^{19}$, os opositores ao Projeto argumentavam que a pretensão de atribuir direitos da órbita da família a tais uniões - por meio da instituição de um "casamento homossexual" - seria inconstitucional, haja vista a definição de família prevista no art. 226, $\S \S 3^{\circ}$ e $4^{\circ}$, da Constituição Federal. Por sua vez, os defensores do Projeto argumentavam que seu escopo seria garantir o cumprimento do dispositivo constitucional que assegura a igualdade de todos perante a lei, caracterizando os direitos previstos aos casais homossexuais como inerentes à cidadania $e$ aos direitos humanos. Neste embate jurídico, os defensores da legitimidade das uniões homossexuais foram forçados a diluir o objetivo do Projeto - o qual seria, de fato, conferir às uniões homossexuais os direitos conjugais já assegurados aos casais heterossexuais, ainda que sem propor a legalização de um "casamento gay" - na esfera abstrata da cidadania e dos direitos humanos, enquanto seus opositores, ao se engajarem numa luta política clara, curvaram-se à evidência de que a família não é um dado "natural" ou "divino", como argumentavam, mas o resultado de um acordo social, historicamente determinado, onde são definidos quais vínculos afetivo-sexuais devem ser reconhecidos, pelo Estado, como geradores de direitos civis de ordem conjugal e parental.

Por outro lado, os opositores ao Projeto, em geral fundados numa leitura religiosa da homossexualidade, entendem que lésbicas e gays são livres para estabelecer os vínculos afetivosexuais que quiserem, mas não teriam o direito de reivindicar a proteção do Estado para relações fundadas nos "apelos da sensualidade" e não em um "amor verdadeiro". Semelhantes

${ }^{19} \mathrm{Em} \mathrm{03.09.03,} \mathrm{o} \mathrm{Senador} \mathrm{Sérgio} \mathrm{Cabral} \mathrm{(PMDB/RJ)} \mathrm{e} \mathrm{mais} 26$ senadores apresentaram a Proposta de Emenda Constitucional (PEC) $n^{\circ} 70 / 2003$, que altera o $\S 3^{\circ}$ do art. 226 da Constituição Federal, com o objetivo de "permitir a união estável entre casais homossexuais", ainda que a possibilidade de casamento continue restrita ao âmbito dos casais heterossexuais. A aprovação de uma PEC pressupõe votação em dois turnos e apoio de 3/5 dos parlamentares, tanto na Câmara dos Deputados quanto no Senado Federal. 
Outras famílias

relações não passariam da materialização de um misto de pecado, doença, crime e mau-caratismo, numa afronta à sociedade, à natureza e a Deus. $\mathrm{O}$ direito à liberdade de orientação sexual não é concebido, assim, como a garantia de usufruto dos direitos decorrentes do exercício desta liberdade no contexto de uniões afetivo-sexuais estáveis. Segundo esses parlamentares, tal entendimento não pode ser compreendido como discriminação ou violação dos direitos humanos e de cidadania, uma vez que seriam os próprios homossexuais que deliberadamente autodiscriminam-se, quando se recusam a ingressar na norma heterocêntrica, supostamente franqueada a todos. $\mathrm{O}$ não reconhecimento das uniões homossexuais como entidades familiares fundamenta-se, também, na compreensão de que a homossexualidade é uma imoralidade e que os homossexuais, conseqüentemente, não devem ser estimulados a permanecer no terreno da "marginalidade" e do "desvio", mas ao invés, devem ser reintegrados socialmente, por meio da conversão - no sentido religioso mesmo - ao universo heterossexual, supostamente o único capaz de proporcionar felicidade e realização pessoal, por atender aos preceitos da moral cristã.

Os parlamentares que defendiam a aprovação do Projeto, por outro lado, apesar de evitarem qualquer referência aos casais homossexuais como unidades familiares $e$ ao contrato de união/parceria civil como sinônimo de casamento, reconhecem que a liberdade de orientação sexual vigente no país teria como implicação a necessidade de reconhecimento da igualdade dos casais homossexuais e heterossexuais na esfera pública, com vistas à superação da discriminação que atinge lésbicas e gays. São recorrentes, também, as comparações entre as discussões relativas ao Projeto e aquelas que antecederam o amparo legal ao divórcio $e$ às uniões concubinárias, também pautadas por forte oposição religiosa. Na perspectiva desses parlamentares, um Estado laico não poderia tornar-se refém de concepções religiosas que negam a dimensão histórica e social da família, numa implícita alusão ao fato de que as uniões homossexuais seriam, também, entidades 
familiares, fundadas por sujeitos que, ao não poderem decidir livre $e$ racionalmente acerca de sua orientação sexual, terminam sendo involuntariamente excluídos dos direitos restritos ao universo da norma heterocêntrica. Entre tais parlamentares, poucos são os que se referem ao amor como fundamento das uniões homossexuais, embora este pareça ser um pressuposto implícito na defesa do tratamento isonômico, na esfera pública, para uniões homo e heterossexuais.

Ainda no tocante aos posicionamentos expressos pelos parlamentares nos debates na Câmara dos Deputados, cumpre dizer que as resistências ao reconhecimento de direitos parentais a lésbicas e gays, especialmente no âmbito do casal conjugal, também se fizeram presentes, inclusive entre alguns daqueles que defenderam a necessidade de amparo legal à conjugalidade homossexual. Geralmente tal resistência fundava-se no entendimento de que a homossexualidade é um mal que por si só implica a negação da competência moral de lésbicas e gays para socializar crianças, além da compreensão de que pais homossexuais colocam seus filhos sob o risco de também se tornarem homossexuais. O preconceito a que estas crianças estariam sujeitas em função da orientação sexual de seus pais foi outro argumento apresentado, sendo o único prevalecente quando a resistência ao direito à socialização de crianças foi manifestada por parlamentares favoráveis ao Projeto. Note-se, porém, que muitos parlamentares, especialmente entre os que defendiam a aprovação do Projeto, sumariamente não se manifestaram acerca desta questão, talvez por entenderem que a mesma não era objeto de discussão, uma vez não contemplada na proposição. Na versão original do Projeto de Lei n ${ }^{\circ} 1151 / 95$, não há qualquer referência - seja proibindo, seja autorizando - à adoção de crianças por casais homossexuais. Já no Substitutivo proposto pelo Relator, Deputado Roberto Jefferson, e aprovado pela Comissão Especial, fica estabelecido que, no contrato de parceria civil registrada entre pessoas do mesmo sexo, não pode constar quaisquer disposições sobre adoção, tutela ou guarda de 
Outras famílias

crianças ou adolescentes em conjunto, mesmo que sejam filhos de um dos parceiros. ${ }^{20}$

Por outro lado, vê-se que todos os representantes da sociedade civil que atuaram como expositores em audiências públicas da Comissão Especial defenderam a aprovação do Projeto como uma decorrência da necessidade de garantia dos direitos humanos e de cidadania dos homossexuais, geralmente também se referindo ao fato de que a ciência não reconhece a homossexualidade como doença ou desvio. $\mathrm{O}$ expositor originário da Igreja Católica foi o único a privilegiar a ótica religiosa em seu pronunciamento, mesmo assim apresentando argumentos favoráveis e contrários ao amparo legal à conjugalidade homossexual, desconsiderando, inclusive, o posicionamento oficial da $\mathrm{CNBB}^{21}$ Prevaleceu entre os expositores o não posicionamento expresso acerca da natureza dos vínculos que unem homossexuais em uma relação estável, tratando-se a questão na perspectiva da ausência de fundamentos médicos, psicológicos, jurídicos e sociais que justifiquem $o$ não reconhecimento da legitimidade das uniões afetivo-sexuais entre pessoas do mesmo sexo.

Assim, seja por meio da definição explícita das uniões homossexuais como entidades familiares, fundadas no amor conjugal, seja pela analogia entre união civil homossexual e união estável heterossexual, seja pelo entendimento de que aos

${ }^{20}$ Para uma discussão sobre parentalidade e homossexualidade no Brasil, ver Grossi, Miriam Pillar. Gênero e parentesco: famílias gays e lésbicas no Brasil. Cadernos Pagu (21), Núcleo de Estudos de Gênero - Pagu /Unicamp, 2003, pp. 261-280, e Uziel, Anna Paula. Família e Homossexualidade: velhas questões, novos problemas. Tese de Doutorado. Ciências Sociais, IFCH-Unicamp, 2002.

${ }^{21}$ No Brasil, uma voz dissonante no coro doutrinário católico tem sido a do Padre José Antonio Trasferetti que, além de criar uma "Pastoral Gay" na cidade de Campinas, publicou o livro Pastoral com homossexuais (Petrópolis, Vozes, 1998), no qual destaca: "Entendo que o projeto da deputada [Projeto de Lei n" 1151/95] pode ser útil na medida em que procura disciplinar um comportamento presente na sociedade e já em grande parte incorporado à nossa cultura e ao nosso modo de viver, quer queiramos ou não" (pp.110-111). 
parceiros de uniões homossexuais devem ser assegurados direitos patrimoniais e previdenciários - os quais são constitutivos da idéia de família também no contexto heterossexual - todos os expositores propõem, direta ou indiretamente, a ruptura da norma heterocêntrica e o conseqüente alargamento do sentido de família, de forma a incorporar, no leque das relações socialmente definidas como conjugais, as uniões homossexuais. Note-se que as discussões acerca do direito de lésbicas e gays à parentalidade foram absolutamente secundárias - se não ausentes - no contexto dos pronunciamentos dos expositores, havendo apenas um único que se posicionou radicalmente contra.

Já no que diz respeito aos relatórios dos encontros promovidos pelo movimento político organizado em defesa da cidadania e dos direitos humanos de gays, lésbicas e travestis no Brasil $^{22}$, assim como na esfera da revista SuiGeneris ${ }^{23}$, observa-se

\footnotetext{
${ }^{22}$ A utilização de relatórios de encontros organizados por grupos de militância homossexual como fonte de pesquisa empírica fundamenta-se no pressuposto de que, em tais eventos, são discutidas questões de interesse da população homossexual brasileira, ainda que, seguramente, não se possa dizer que a militância homossexual no Brasil contemple a totalidade das demandas $e$ interesses dos homossexuais que não estão ligados a grupos politicamente organizados. Não há dúvidas, porém, de que o movimento homossexual no Brasil tem sido uma instância importante na produção e encaminhamento de demandas por direitos civis na arena política nacional, pelo menos desde fins dos anos 70 do século 20

${ }^{23}$ A SuiGeneris foi uma revista comercializada nacionalmente, em bancas de jornais, ao preço de $\mathrm{R} \$ 5,90$ (março/2000) e com tiragem média de mais de 20 mil exemplares. Em seus cinco anos de circulação, produziu 55 edições. No primeiro número, é apresentada como uma revista de "cultura, moda, comportamento \& entretenimento", sendo definida, no Editorial, como "a primeira revista brasileira a trazer discernimentos sérios e futilidades chics dirigidas para homens e mulheres gays. Mas sem exclusividade". O mesmo editorial enfatiza, ainda: "Nossa intenção é levar a cultura gay de forma vibrante, inteligente, alegre, para fora dos guetos. Dar nossa contribuição, oferecendo um jornalismo de qualidade, para que surja em breve uma consciência social mais generalizada de que nossas semelhanças são maiores que nossas diferenças. Porque a gente é gay e igual a todo mundo". Com esse perfil, parece inegável que a SuiGeneris pretendia-se uma divulgadora dos interesses da "comunidade
} 
Outras famílias

que são recorrentes as demandas acerca do reconhecimento social $e$ jurídico da dimensão familiar das uniões homossexuais, incluindo direitos conjugais e, em menor escala, parentais. Tais uniões, mesmo quando sem filhos, são concebidas como expressão de uma conjugalidade equivalente ao casamento heterossexual $e$ à união estável entre homem e mulher, devendo receber, por conseguinte, tratamento igualitário na esfera pública. Os direitos parentais de lésbicas e gays, no âmbito da monoparentalidade ou do casal conjugal, são defendidos a partir do argumento de que a orientação sexual homossexual não é incompatível com o exercício da paternidade e da maternidade, sendo freqüentes as alusões a estudos científicos que apontam a não influência da orientação sexual dos pais na conformação da orientação sexual dos filhos. Nega-se, por outro lado, a legitimidade do argumento segundo o qual homossexuais não devem assumir funções parentais para proteger seus potenciais filhos do preconceito e da discriminação, sendo a superação destes entendida como o caminho para a construção de uma sociedade que respeite tanto adultos homossexuais quanto seus filhos, biológicos ou adotivos, homo ou heterossexuais..

É notório que, principalmente na revista SuiGeneris, existe um cuidado em não se referir à reivindicação de amparo legal às uniões homossexuais como casamento, especialmente nos períodos em que as discussões acerca da união civil entre pessoas do mesmo sexo estavam mais acirradas na Câmara dos Deputados, provavelmente em face do temor de que o discurso dos próprios homossexuais fosse utilizado para reafirmar a suposta inconstitucionalidade do Projeto. Exemplo disso, na esfera do movimento GLBTT, é que antes da apresentação do Projeto de Lei n $1151 / 95$ na Câmara dos Deputados, o ativista Luiz Mott, do Grupo Gay da Bahia, apresentou para discussão o texto "Porque

homossexual" brasileira, não apenas num sentido político, mas também cultural, sem que isso implicasse qualquer vinculação direta a nenhum grupo de militância homossexual. 
sou a favor do casamento gay", em um dos grupos de trabalho do VIII Encontro Brasileiro de Lésbicas e Gays (Curitiba, 1995). Em junho de 1996, quando Luiz Mott participa, como expositor, da primeira audiência pública da Comissão Especial destinada a apreciar e proferir parecer ao Projeto na esfera da Câmara dos Deputados, em nenhum momento faz qualquer alusão à expressão "casamento homossexual", ainda que seja explícita sua defesa da necessidade de reconhecimento da igualdade, na esfera pública, entre uniões homo e heterossexuais. Provavelmente, a preocupação com os debates acerca da constitucionalidade do projeto foi o que motivou a aparente mudança de posicionamento. Para lésbicas e gays, todavia, a conjugalidade e a parentalidade parecem não ter sexo, gênero ou orientação sexual, sendo concebidas apenas como materialização do amor e da busca de felicidade e alegria de viver.

Finalmente, observa-se que a Igreja Católica ${ }^{24}$, em seus documentos doutrinários, define a vivência homossexual como constitutivamente pecaminosa e contesta a legitimidade da reivindicação de direitos conjugais e parentais para lésbicas $e$ gays, além de defender a justeza da discriminação por orientação

${ }^{24} \mathrm{~A}$ opção por trabalhar com o discurso da Igreja Católica acerca das uniões homossexuais, deixando num plano secundário as demais perspectivas religiosas, fundamenta-se na constatação de que o catolicismo é a religião que, no Brasil, possui maior poder de influência sobre o Estado, além de ser oficialmente reconhecida como a religião de mais de $70 \%$ da população. Por outro lado, é a religião que apresenta um corpo doutrinário mais estruturado e unificado, inclusive em relação à homossexualidade, o que proporciona um mais pronto acesso a seu discurso sobre as relações afetivo-sexuais entre pessoas do mesmo sexo. Não existe, porém, termo de comparação entre a influência da Igreja Católica - instituição claramente hierarquizada, com séculos de tradição e um corpo doutrinário unitário e sistematizado - e a da "comunidade homossexual" formada por sujeitos políticos via de regra atomizados, com baixo e recente nível de organização institucionalizada - na conformação dos valores e práticas dominantes na sociedade brasileira, ainda que seja perceptível o decréscimo da ascendência católica no Brasil e no mundo, ao passo que os homossexuais cotidianamente vêm conseguindo ampliar sua luta contra o preconceito e a discriminação. 
Outras famílias

sexual em outras instâncias sociais, como trabalho e moradia. A partir de uma concepção de amor e de família naturalista, fundada na complementaridade dos sexos e dos gêneros e no imperativo da associação entre conjugalidade, sexualidade e reprodução, a Igreja Católica nega que a liberdade de orientação sexual seja um direito humano, advogando a tese de que os homossexuais devem manter-se celibatários ou ingressar, se possível for, no universo da conjugalidade heterossexual.

No entendimento da Igreja Católica, todavia, não haveria discriminação por orientação sexual, haja vista que este atributo, definido como "objetivamente desordenado", não seria comparável a sexo, raça e idade. Ainda que a Igreja Católica afirme defender os direitos humanos e a cidadania dos homossexuais, tal defesa restringe-se ao conjunto das lésbicas e gays que não se envolvem em relações afetivo-sexuais, os quais seriam os únicos capazes de usufruir, como seres humanos dignos, dos benefícios decorrentes da integração social. Responsabilizados individualmente pela decisão de exteriorizarem sua orientação sexual, às lésbicas e gays que transgridam os limites de uma vida afetiva e sexual heterossexual seria legítima e necessária a completa exclusão da órbita de direitos familiares, por ser esta transgressão concebida como uma ameaça aos valores de uma moral, católica, que condena à ilegitimidade toda e qualquer expressão do amor e do desejo sexual que não esteja inscrita no âmbito de um casamento indissolúvel, monogâmico e aberto à reprodução. Na doutrina católica, portanto, os homossexuais que não negam sua orientação sexual são definidos como seres humanos de segunda ordem, o que significa dizer subumanos.

\section{Subvertendo o heterocentrismo}

Por meio da análise dos pronunciamentos realizados na Câmara dos Deputados, por parlamentares e representantes da sociedade civil, assim como de documentos que externam posicionamentos de lésbicas e gays e da Igreja Católica, pode-se 
constatar, então, que o conflito entre uma visão de mundo laica e outra religiosa constitui o núcleo dos embates em torno do reconhecimento da legitimidade da conjugalidade homossexual. Os defensores de tal reconhecimento, seja na sociedade civil, seja no Estado, entendem que a igualdade entre uniões homo $e$ heterossexuais na esfera pública é uma questão de direitos humanos e de cidadania, sendo a família concebida como uma instituição social, cuja proteção legal deve ser atualizada à luz de suas transformações históricas. Por outro lado, os sujeitos políticos que negam aquele reconhecimento o fazem numa perspectiva que concebe a homossexualidade como um comportamento imoral $e$ anti-social, entendendo a eventual extensão de direitos conjugais e parentais a casais homossexuais como uma ameaça aos alicerces da vida em sociedade, uma vez contrariados os pressupostos morais de uma família concebida em termos naturalistas $e$ religiosos, estruturada a partir da diferença sexual. Essa clivagem de ordem religiosa, quando expressa na esfera da Câmara dos Deputados, prevalece, inclusive, sobre a filiação político-partidária dos defensores e opositores ao amparo legal às uniões homossexuais, ainda que haja uma tendência para que os parlamentares que negam a legitimidade social da conjugalidade homossexual a partir de argumentos religiosos estejam filiados a partidos políticos de centro-direita.

Tais conflitos entre uma visão laica e outra religiosa são os mesmos que se fizeram presentes quando da discussão de propostas legislativas que implicaram a ampliação de direitos na esfera da família, a exemplo das relativas ao divórcio e às relações concubinárias. Tais confrontos entre sujeitos sociais que possuem distintas concepções de família emergem, assim, como a materialização dos embates ideológicos entre visões de mundo inclusivas $e$ excludentes. Se as primeiras expressam o entendimento de que a cidadania e os direitos humanos devem ser assegurados ao mais amplo $e$ variado conjunto possível de indivíduos, as segundas ancoram-se na compreensão de que apenas os indivíduos que se enquadram nos limites dos valores $e$ 
Outras famílias

práticas sociais dominantes devem ser reconhecidos, incondicionalmente, como cidadãos e seres humanos.

Embora, na esfera legal, as discussões acerca da conjugalidade homossexual desconheçam especificidades de gênero, referindo-se, indistintamente, a casais de homens e de mulheres, uma especificidade de gênero mostra-se particularmente relevante na compreensão dos rumos tomados pelos debates envolvendo o Projeto: enquanto sua autora é uma mulher $e$ feminista, a possibilidade de sua efetiva aprovação está a depender dos homens, os quais constituem maioria absoluta no Congresso Nacional, assim como nos núcleos dirigentes das instituições religiosas, cujos pressupostos morais estruturam os posicionamentos contrários assumidos pelos parlamentares. Para além do heterocentrismo, portanto, o androcentrismo ainda tem sido uma forte característica dos debates relativos não só à homossexualidade, mas também à família, onde a um Estado controlado basicamente por homens associam-se, como atores sociais importantes, igrejas, cujos postos de comando também são ocupados por homens, que pautam sua atuação política a partir de crenças e valores socialmente definidos como masculinos, muitas vezes numa feição claramente machista. ${ }^{25}$

A despeito da inexistência de uma proteção jurídica expressa e inequívoca, observa-se que o processo de construção social da conjugalidade homossexual aponta para a afirmação do entendimento de que as relações afetivo-sexuais estáveis entre gays e entre lésbicas vêm se materializando como uma das novas formas de institucionalização de vínculos familiares no Brasil, principalmente quando se tem em vista a crescente legitimidade da autonomização da sexualidade em relação à reprodução e à

${ }^{25}$ Uma estimulante reflexão acerca das distinções conceituais entre sexo e gênero pode ser encontrada em PISCITELli, Adriana. Ambivalência sobre os conceitos de sexo e gênero na produção de algumas teóricas feministas. In: AGUIAR, Neuma. (org.) Gênero e ciências humanas: desafios às ciências desde a perspectiva das mulheres. Rio de Janeiro, Record/Rosa dos Tempos, 1997. 
conjugalidade $e^{26}$, o questionamento da dimensão supostamente natural da família e do sistema de sexo e gênero ${ }^{27}$ e a ampliação do campo semântico das noções de direitos humanos e de cidadania, de forma a englobar os direitos sexuais $e$ reprodutivos. $^{28}$ Se a afirmação da conjugalidade homossexual como entidade familiar que rompe os limites da norma heterocêntrica já parece um fato entre os próprios homossexuais, este entendimento também tem se mostrado cada vez mais freqüente entre outros segmentos sociais e mesmo na esfera do Estado, especialmente em função de recentes decisões do Poder Judiciário, as quais sinalizam o reconhecimento jurisprudencial da dimensão familiar da conjugalidade homossexual e da garantia do direito à parentalidade a lésbicas e gays. ${ }^{29} \mathrm{O}$ Instituto Nacional de Seguridade Social (INSS), por exemplo, já prevê a concessão de benefício às pessoas do mesmo sexo que mantenham relação afetivo-sexual estável, com base no disposto na Instrução Normativa n. ${ }^{\circ}$ 25, de 07.06.00, que é decorrente de ação civil pública. Daí talvez advenha o temor de que o ingresso dos homossexuais na esfera das práticas social e juridicamente definidas como familiares possa radicalizar ainda mais a "crise da

${ }^{26}$ PARKER, Richard e BARBOSA, Regina Maria. (orgs.) Sexualidades Brasileiras. Rio de Janeiro, Relume Dumará/ABIA/IMS-UERJ, 1996.

${ }^{27}$ Bozon, Michel. Sexualidade e conjugalidade. As reformulações das relações de gênero. Cadernos Pagu (20), Núcleo de Estudos de Gênero - Pagu, Unicamp, 2003, pp.131-156; HEILBORN, Maria Luiza e SoRJ, Bila. Estudos de gênero no Brasil. In: MicELI, Sérgio. (org.) O que ler na ciência social brasileira (1970-1995) - Sociologia (volume II). São Paulo, Brasília, Sumaré/ANPOCS/CAPES, 1999; RoudinESCO, Elisabeth. A familia em desordem. Rio de Janeiro, Zahar, 2003.

${ }^{28}$ BruschinI, Cristina e Unbehaum, Sandra G. (orgs.) Gênero, democracia e sociedade brasileira. São Paulo, FCC/Ed. 34, 2002; CORRÊA, Sonia e ÁvILA, Maria Betânia. Direitos sexuais e reprodutivos. Pauta global e percursos brasileiros. In: BERQUÓ, Elza. (org.) Sexo \& Vida: panorama da saúde reprodutiva no Brasil. Campinas-SP, Editora da Unicamp, 2003, pp.17-78.

${ }^{29}$ Rios, Roger Raupp et alii. A justiça e os direitos de lésbicas e gays. Porto Alegre, Sulina, 2003; RIOS, Roger Raupp. Princípio da igualdade e a discriminação por orientação sexual. São Paulo, Revista dos Tribunais, 2002. 
Outras famílias

família" e a "desestruturação familiar", ${ }^{30}$ objeto de tantos discursos entre os defensores de uma moral com pretensões de validade universal e de um modelo de família universal, os quais reagem com indignação e intolerância a todas as transformações que os próprios heterossexuais produzem em suas famílias, redefinindo valores, hábitos, tradições e comportamentos até recentemente compreendidos como "naturais", "sagrados" e, portanto, imutáveis.

Assim, o processo de construção da conjugalidade homossexual situa-se no contexto mais amplo de todas as transformações que vêm atingindo as representações e práticas sociais relativas à família, especialmente nas últimas três décadas, período em que a expansão de fenômenos como o divórcio, a monoparentalidade, as uniões estáveis, as famílias recompostas, os casais sem filhos e a gravidez na adolescência e na maturidade tornou-se a expressão concreta de que a família no Brasil de hoje não é a mesma de algumas poucas décadas atrás ${ }^{31}$, quando se entendia que a única família legítima era a formada a partir dos pressupostos de uma moral católica, consagrada nas representações e práticas sociais e no ordenamento jurídico então vigente.

Essencialismos à parte, há diferenças importantes entre as experiências de conjugalidade homossexual e heterossexual, a começar pelo preconceito e discriminação sociais que atingem a primeira, pela limitação da possibilidade de reprodução biológica sexuada apenas à segunda e pelas especificidades de gênero que atribuem singularidade a cada um dos três tipos de casal: o formado por um homem e uma mulher, o constituído por duas mulheres e o integrado por dois homens. ${ }^{32}$ Todavia, para além

${ }^{30}$ GoldAnI, Ana Maria. As famílias no Brasil contemporâneo e o mito da desestruturação. Cadernos Pagu (1), Núcleo de Estudos de GêneroPagu/Unicamp, 1993, pp.67-110.

${ }^{31}$ OsóRIO, Luiz Carlos. Família hoje. Porto Alegre, Artes Médicas, 1996.

${ }^{32}$ Maria Luiza Heilborn aponta algumas tendências interessantes no âmbito desta questão: "Os gays, de um lado, são atraídos para o modelo heterossexual, visto 
destas especificidades, quando se pensa a conjugalidade a partir de projetos identitários plurais ${ }^{33}$ e de uma concepção não rígida dos sistemas de sexo e de gênero, o que se observa é que um homem e uma mulher, duas mulheres ou dois homens podem, igualmente, partilhar investimentos afetivos e materiais e construir conjuntamente estratégias e hábitos de vida destinados a lhes proporcionar gratificação afetivo-sexual, segurança existencial $e$ material e realização de projetos individuais e coletivos, ao longo do tempo em que estiverem juntos, seja como "casal romântico", seja como "casal confluente". ${ }^{34}$

A luta dos homossexuais pelo reconhecimento da legitimidade de suas relações afetivo-sexuais reproduz, então, uma trajetória já trilhada em relação aos atributos raça, etnia, religião, nacionalidade, geração, classe social e nível de escolaridade, entre outros, os quais deixaram de ser definidos, no contexto da sociedade brasileira, como determinantes na definição dos sujeitos que estão socialmente autorizados a se elegerem como cônjuges na construção de uma unidade familiar - ainda que permaneça uma tendência para a valorização social dos casais homogâmicos. O objetivo último desta reivindicação parece ser a consagração do entendimento de que quaisquer duas pessoas que se elejam como parceiros afetivo-sexuais, independentemente de orientação sexual, devem ser vistas como um casal conjugal, podendo usufruir, indistintamente, dos direitos civis, na esfera das relações

que existe a polaridade ativo/passivo, e de outro lado, como são mais simétricos (na administração burocrática do lar) do que o casal hetero, são capturados pelo modelo do casal feminino. E as mulheres homossexuais levariam ao extremo aquilo que é preconizado pela conjugalidade igualitária, sendo que isso parece implicar uma menor eroticidade da relação. A rigor, o contraste entre as modalidades conjugais parece apontar para a realização de uma maior simetria entre as mulheres". HEILBORN, M. L. Gênero e hierarquia. A costela de Adão revisitada. Revista de Estudos Feministas, vol. 1, n 1, $1^{\circ}$ semestre de 1993, p.76.

${ }^{33}$ Hall, Stuart. A identidade cultural na pós-modernidade. Rio de Janeiro, DP\&A, 2001.

${ }^{34}$ GIDDENS, Anthony. A transformação da intimidade: sexualidade, amor $e$ erotismo nas sociedades modernas. São Paulo, Editora da USP, 1993. 
Outras famílias

familiares, assegurados pelo Estado. A Prefeitura de Recife e o Estado do Rio de Janeiro já dispõem de instrumentos legais que asseguram benefícios a companheiro/a homossexual. Deve ser registrado, também, que o Congresso Nacional tem dado sinais de que as reivindicações da população homossexual começam a encontrar maior acolhida no cenário político nacional, como se pode observar a partir dos debates realizados no Seminário "Políticas Afirmativas e Direitos da Comunidade GLBTT", promovido pela Ouvidoria Parlamentar da Câmara dos Deputados, em junho de 2003. A partir deste seminário, foi criada, em outubro do mesmo ano, a "Frente Parlamentar pela Livre Expressão Sexual", que tem por objetivo principal articular a aprovação de legislação federal de interesse de lésbicas, gays, travestis e transexuais, contando com a adesão inicial de 44 parlamentares.

Assim, numa perspectiva sociológica, pode-se dizer que as relações amorosas estáveis entre homossexuais começam a ser vistas como uma das modalidades de família que passa a ganhar visibilidade social no final do século $\mathrm{XX}$, com o casal conjugal sendo concebido menos como grupo organizado e hierarquizado, destinado à reprodução biológica, e mais como espaço de exercício de amor e de cooperação mútua, consagrado à reprodução social. Considerando o forte teor integracionista das reivindicações do movimento homossexual no Brasil, um desafio que começa a se colocar na ordem do dia é o de pensar sobre as conseqüências de uma reprodução acrítica do modelo familiar moderno no âmbito das relações entre pessoas do mesmo sexo. Longe de qualquer pretensão queer ${ }^{35}$, parece cada vez mais que

${ }^{35}$ Para uma discussão sobre teoria queer, ver JiMÉNEZ, Rafael Mérida. (ed.) Sexualidades transgressoras: uma antologia de estúdios queer. Barcelona, Içaria, 2002. Sobre o conceito queer - como modelo não identitário, antiassimilacionista e performático - ver BARCELLOS, José Carlos. Literatura e homoerotismo masculino: perspectivas teórico-metodológicas e práticas críticas. In: SOUZA JÚNIOR, José Luiz Foureaux de. (org.) Literatura e homoerotismo: uma introdução. São Paulo, Scortecci, 2002; LoURO, Guacira Lopes. Teoria queer uma política pós-identitária para a educação. Estudos feministas, vol. 9, n² 2 , 
Luiz Mello

as lésbicas e os gays brasileiros não estão dispostos a serem eternamente tios e tias. O casamento, quem diria, será o grande tesouro embaixo do arco-íris?

2001, pp.541-553; SwAIN, Tânia Navarro. Para além do binário: os queers e o heterogêneo. Gênero - Revista do Núcleo Transdisciplinar de Estudos de Gênero, vol. 2, n $1,2^{\circ}$ semestre de 2001, pp.87-97. 